Jurnal Basicedu Volume 3 Nomor 4 Tahun 2019 Halaman 1005-1013

JURNAL BASICEDU

Research \& Learning in Elementary Education

https://jbasic.org/index.php/basicedu

\title{
PENGEMBANGAN MEDIA PEMBELAJARAN BUDAYA MELAYU DENGAN ADOBE FLASH BERBASIS KEARIFAN LOKAL DI SEKOLAH DASAR
}

\author{
Gihari Eko Prasetyo ${ }^{1}$, Nurlia Ginting ${ }^{2}$ \\ Universitas Quality Berastagi ${ }^{1,2}$ \\ Email gihari.eko@gmail.com ${ }^{1}$
}

\begin{abstract}
Abstrak
Tujuan dilaksakannya penelitian ini adalah menciptakan media pembelajaran untuk tingkat sekolah dasar di kabupaten langkat, pengembangan dilakukan dengan menggunakan aplikasi adobe flash yang berbasis kearifan lokal budaya melayu langkat, dengan menggunakan model Pengembangan 4D Thiagarajan yaitu : Define, Design, Develop, dan Diseminate. Dimana dalam proses pengembangannya harus memenuhi aspek Valid, Praktis, dan Efektif, dimana hasil validitas ketiga validator dari media ini dalam kategori sangat valid dengan rata-rata $85 \%$, kepraktisan mencapai persentase sebesar 92\% dalam kategori baik, ketercapain $N$-gain dalam kategori tinggi sebesar 0,33
\end{abstract}

Kata Kunci: Media, Kearifan Lokal, Melayu

\begin{abstract}
The purpose of this research to create learning media for elementary school in Langkat, the development is carried out using Adobe Flash application based on local wisdom of Malay culture by using the 4D Thiagarajan Model's. There are 4 steps : Define, Design, Develop, and Diseminate. Where in the development process must be Valid, Practical, and Effective, where the results the validity of the three validators from this media are in the very valid category with an average of $85 \%$, practicality reaches a percentage of $92 \%$ and in good category, the achievement of $N$-gain in the category high of 0.33
\end{abstract}

Keywords: Media, Local Wisdom,Malay

@ Jurnal Basicedu Prodi PGSD FIP UPTT 2019

$\triangle$ Corresponding author :

Address :

Email :

ISSN 2580-3735 (Media Cetak)

Phone 


\section{PENDAHULUAN}

Manusia terlahir memiliki keunikan dan ciri-ciri yang berbeda satu dengan yang lain, seperti bentuk tubuh, kromosom, warna kuilit, dan lain lain. Dilihat dari culture (Budaya), manusia hidup dan dibesarkan oleh lingkungan sekitar yang berbeda-beda, namun pada batas tertentu manusia memilki kesamaan dan kemiripan atau bahkan perbedaan yang sering disebut kemajemukan. Kemajemukan ini yang menghadirkan adanya permusuhan dan persaudaraan.

Melihat karakter masyarakat Kabupeten langkat yang mayoritas adalah bersuku melayu, (Rusman : 2012) Masyarakat asli di suatu daerah memiliki cara pandang, wawasan dan konsep terkait lingkungan mereka. Yang biasa kita sebut kearifan lokal. Penanaman sikap saling menghargai di dasarkan oleh kearifan lokal yang berlaku di masyarakat sekitar agar tidak terjadi clash antar berkehidupan bermasyarakat. Melihat fenomena diatas, perlu adanya nilai-nilai budaya yang ada di pahami oleh seluruh masyarakat agar menciptakan rasa saling menghormati dan menghargai antar suku dan budaya. Masa Sekolah Dasar merupakan waktu yang tepat untuk menanamkan rasa mencintai budaya dan menghargai budaya lain guna menanamkan rasa saling menghargai antar berbagai suku khususnya di kabupaten Langkat.

Melalui media pembelajaran yang dikembangkan oleh pendidik, menjadikan solusi yang tepat dalam upaya membangun sikap saling menghargai. Dengan kemajuan teknologi yang semangkin berkembang, Pembelajaran sudah beralih ke arah multimedia digital, Komputer dalam perkembangan masa kini merupakan suatu peralatan yang canggih dan dapat dimanfaatkan diantaranya dalam masalah pendidikan dan pembelajaran.
Adobe Flash yang menggunakan model tutorial merupakan aplikasi yang mendukung untuk dikembangkan menjadi media pembelajaran, dengan berbagai fitur yang tersedia di dalamnya membuat pengembang dapat berkreasi untuk menciptakan media pembelajaran yang berkualitas, sehingga nantinya akan dapat meningkatkan pemahaman belajar siswa. Ada beberapa kelebihan diantaranya, hasil akhir file (setelah di publish) sangat rendah dan ringan sehingga mudah untuk digunakan Useable, dan hasil dari produk ini dapat digunakan ke seluruh spesifikasi computer.

Berangkat dari hasil pemikiran diatas, Pengembangan media pembelajaran menggunakan Komputer berbasis Kerarifan lokal dalam pembelajaran, yakni dengan membuat software pembelajaran multimedia interkatif dari adobe flash, Salah satu aplikasi yang digunakan dalam pembuatan media yang dapat mensimulasikan kehidupan sehari-hari adalah Adobe Flash CS6.

Dengan berbagai fitur canggih yang ada didalamnya sangat membantu membuat beragam animasi. Pengembanagan media tersebut sangat perlu dilakukan, hal tersebut bertujuan untuk memfasilitasi peserta didik dalam membangun sikap saling menghargai antar suku dan budaya.

\section{METODE}

Penelitian ini merupakan jenis penelitian R\&D (Research and Development). Penelitian ini dilaksanakan dengan tujuan untuk mengembangkan dan menghasilkan sebuah produk sebagai suatu upaya penanaman sikap saling menghargai berbasis kearifan lokal budaya melayu. Produk yang akan dihasilkan dalam peneltian ini yaitu Media pembelajaran berbasis komputer berupa aplikasi untuk tingkat Sekolah Dasar.

Nienke (2013:29) Model pengembangan yang akan direncanakan dalam penelitian ini mengikuti alur dari Sivasailam Thiagarajan yaitu 
1007 Pengembangan media pembelajaran budaya melayu dengan adobe flash berbasis kearifan lokal di sekolah dasar - Gihari Eko Prasetyo, Nurlia Ginting

Model 4-D (four D models) yang terdiri dari 4 tahap, yaitu: (1) tahap pendefenisian (degine), (2) tahap perencanaan (design), (3) tahap pengembangan (develop) dan (4) tahap penyebaran (disseminate).

Penelitian ini akan dilaksanakan di Kabupaten Langkat, Sumatera Utara . Waktu penelitian akan dilakukan pada Bulan Mei sampai Agustus. Subjek pada penelitian ini adalah siswa SD Negeri 050664 Lubuk dalam sebagai sekolah uji coba. Objek dalam penelitian ini adalah media pembelajaran menggunakan Adobe Flash

Penelitian akan dilaksanakan berdasarkan mekanisme yang telah dipilih.. Ada empat tahap yang akan dilakukan yaitu : Tahap define adalah suatu tahap yang dilakukan untuk menetapkan dan mendefinisikan syarat-syarat yang dibutuhkan dalam pengembangan pembelajaran yang disesuaikan dengan kebutuhan yang ada di lapangan lokasi penelitian. Pada tahap Design dilakukan penyusunan draft awal (draft I) untuk merancang contoh (prototipe) media pembelajaran. Informasi yang di dapat pada tahap define kemudaian di kembangkan sehingga di dapat draft awal. Selanjutnya Tahap Develop pengembangan ini dilakukan untuk menghasilkan draft final yang baik, yang telah direvisi berdasarkan masukan dari para ahli serta di validasi oleh tokoh masyarakat setempat. Tahap pengembangan yang diajukan guna menganalisis, menguji coba, mengembangkan, mengevaluasi dan merevisi media pembelajaran. Dan yang terakhir tahap Disseminate merupakan tahap akhir dari proses pengembangan produk dengan model 4-D Thiagarajan.

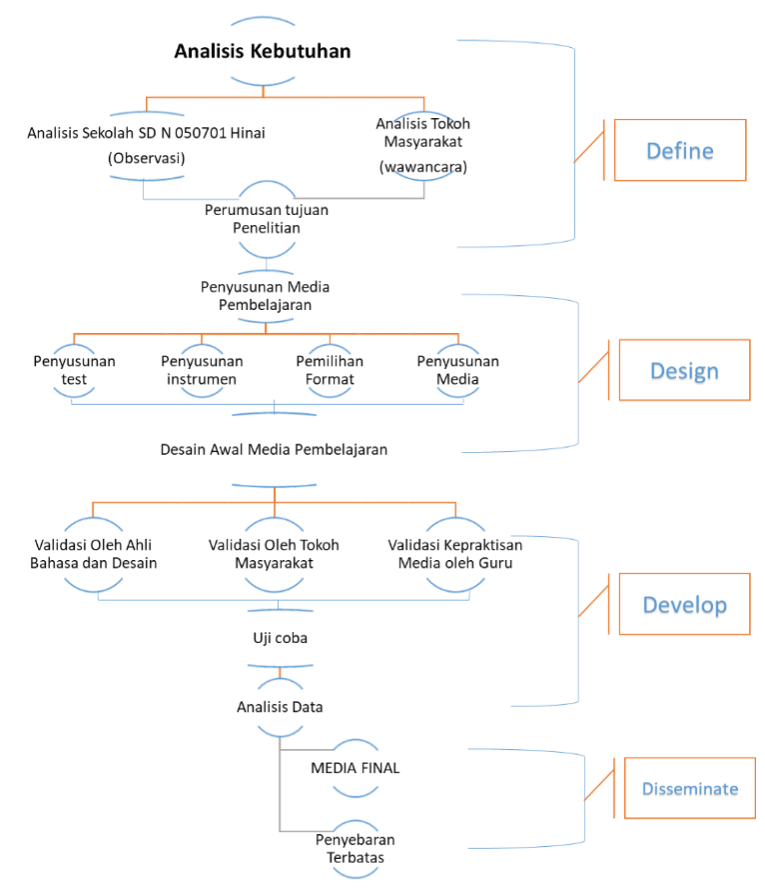

Gambar 1. Gambar model 4-D Thiagarajan. 6)Instrumen Pengumpulan Data

Table 1. Keterkaitan Instrumen

\begin{tabular}{|c|c|c|c|}
\hline Target & Instrumen & \multicolumn{2}{|l|}{ Subjek } \\
\hline & Valid & Angket & $\begin{array}{l}\text { Ahli Media } \\
\text { dan desain } \\
\text { Ahli } \\
\text { Bahasa } \\
\text { Ahli Materi }\end{array}$ \\
\hline & Efektif & $\begin{array}{l}\text { Tes hasil } \\
\text { Belajar }\end{array}$ & Siswa \\
\hline & Praktis & Angket & Guru \\
\hline
\end{tabular}

Instrumen angket berupa lembar penilaian dalam bentuk lembar validasi berisi butir-butir penilaian untuk setiap aspek, baik aspek pembelajaran, aspek isi/materi, aspek tampilan maupun aspek pemograman yang akan diisi oleh ahli media dan desain, ahli materi, User/Guru dan subjek uji coba. Sedangkan instrument tes merupakan tes pengetahuan siswa tentang kearifan local budaya Melayu. Soal tes berjumlah 20 butir soal dalam bentuk pilihan ganda. Instrumen validasi di ambil berdasarkan penelitian penliti yang lalu, serta soal yang digunakan untuk di uji coba telah melalui validasi oleh ahli materi.

Data angket validasi ahli dianalisis menggunakan persentase skor media pembelajaran yang dikembangkan. Rumus yang digunakan untuk menghitung presentase angket validasi ahli yaitu: 
1008 Pengembangan media pembelajaran budaya melayu dengan adobe flash berbasis kearifan lokal di sekolah dasar - Gihari Eko Prasetyo, Nurlia Ginting

$$
P=\frac{f}{N} x 100 \%
$$

Keterangan:

$\begin{array}{lll}\mathrm{P} & : & \text { Presentase skor } \\ \mathrm{f} & : & \text { jumlah skor yang diperoleh } \\ \mathrm{N} & : & \text { jumlah skor maksimul }\end{array}$

Menurut Sudjana (2007:91) penentuan kriteria validasi yaitu:

Tabel 2. Keterkaitan Instrumen

\begin{tabular}{|l|l|}
\hline $\begin{array}{l}\text { Tingkatan } \\
\text { Pencapaian }\end{array}$ & $\begin{array}{l}\text { Klasifikasi } \\
\text { Validitas }\end{array}$ \\
\hline $81,26 \%<\mathrm{P} \leq 100 \%$ & Sangat valid \\
\hline $62,26 \%<\mathrm{P} \leq 81,25 \%$ & Valid \\
\hline $43,76 \%<\mathrm{P} \leq 62,25 \%$ & Kurang valid \\
\hline $25 \%<\mathrm{P} \leq 43,75 \%$ & Tidak valid \\
\hline
\end{tabular}

N-Gain adalah normalisasi gain yang diperoleh dari hasil pretest dan posttes, perhitungan nilai rata-rata N-Gain dilakukan untuk melihat peningkatan hasil belajar siswa, dari nilai $\mathrm{N}$-gain tersebut akan dilihat peningkatan penggunaan media pembelajaran menggunakan adobe yaitu dengan rumus sebagai berikut :

N Gain $=\frac{S_{\text {postest }}-S_{\text {pretest }}}{S_{\text {maksimum }}-S_{\text {pretest }}}$

Interpretasi N Gain menurut sudijono disajikan pada table 4.7. berikut:

Tabel 3. Klasifikasi Interpretasi N Gain

\begin{tabular}{|c|c|}
\hline Besar Presentase & Interprtasi \\
\hline $\mathrm{g}>0,7$ & Tinggi \\
\hline $0,3<\mathrm{g}<0,7$ & Sedang \\
\hline $\mathrm{g}<0,3$ & Rendah \\
\hline
\end{tabular}

Uji coba merupakan bentuk evaluasi formatif yang bertujuan untuk mengetahui ke efektifan suatu media yang dikembangkan. yang dilakukan dengan cara meminta penilaian orang lain untuk mencoba produk yang dikembangkan. Tujuan utama dilakukannya Uji coba menghasilkan temuan tentang kelemahan, kekurangan, kesalahan produk dan saran-saran. Tujuan uji coba ini adalah untuk mengetahui kualitas dari produk media yang dikembangkan dan apakah multimedia interaktif ini layak atau tidak untuk digunakan. Setelah produk multimedia pembelajaran interaktif jadi, maka dilakukan uji akhir produk dan memberikan penilaian (judgment) untuk mengetahui efektivitas produk yang dihasilkan. Uji coba efektivitas menggunakan uji dengan membandingkan hasil pretest dengan posttest dengan mencari Nilai Normalitas Gain (NGAIN) Instrumen Pengumpulan Data Instumen angket berupa lembar penilaian dalam bentuk lembar validasi berisi butir-butir penilaian untuk setiap aspek, baik aspek media dan desain, aspek isi/materi, aspek Bahasa maupun aspek kepraktisan yang akan diisi oleh ahli media, ahli materi, ahli bahasa dan guru,subjek uji coba.

\section{HASIL DAN PEMBAHASAN}

Penelitian ini telah menghasilkan sebuah produk penelitian berupa Media pembelajaran, Media pembelajaran yang dikembangkan, dinyatakan layak digunakan jika media tersebut valid, praktis, dan efektif. Dikatakan valid jika telah di validasi oleh ahli materi, validasi ahli media dan desaindan Ahli Bahasa, Media pembelajaran dikatakan praktis jika angket kepraktisan media yang di nilai oleh guru mencapai persentase sebesar 80\%. Kemudian media pembelajaran yang dikembangkan dikatakan efektif jika klasifikasi hasil belajar masuk dalam kategori tinggi.

Pembuatan Media pembelajaran ini menggunakan metode penelitian dan pengembangan (R\&D) model 4-D. Berdasarkan prosedur pengembangan yang sudah dikemukakan pembuatan media pembelajaran dilakukan dalam beberapa tahapan pengembangan untuk menghasilkan produk akhir penelitian, yaitu:

Pada tahap define peneliti melakukan 
observasi awal ke sekolah SD Negeri 050664 Lubuk dalam, ada beberapa hal yang perlu diobservasi, ada lima aspek yang peneliti amati diantaranya, Peserta didik, Pendidik, Sarana dan prasarana, latar belakang siswa, daerah sekitar lingkungan sekolah.

Siswa SD Negeri 050664 Lubuk Dalam secara keseluruhan bejumlah 307 siswa, dengan jumlah laki laki sebesar 162 dan perempuan berjumlah 145, dengan sebaran suku jawa kurang lebih sekitar 50\%, Melayu kurang lebih sekitar 23 $\%$, Batak kurang lebih sekitar 10\% dan selebihnya bersuku, Karo, Banten, Sunda, Mandailing, Padang dan lain lain. Dengan mayoritas siswa di SD Negeri 050664 Lubuk dalam bersuku Jawa maka pemahaman siswa tentang kearifan local budaya melayu masih dinilai rendah. Dari hasil wawancara dengan guru di SD tersebut dengan adanya berbagai macam suku masih terjadi beberapa kasus seperti mengucilkan suku yang minoritas, mengejek, saling bully namun tidak terlalu sering.

Dilihat dari kemampuan siswa mengoprasikan computer tampak mereka sudah terbiasa mengoprasikan computer, karena letak sekolah yang berada di jalan protocol dan banyak penyedia jasa rental computer di sekitar sekolah. Guru juga sering menggunakan media computer untuk menjelaskan berbagai macam pelajaran, jadi mereka merasa penggunaan computer sebagai media pembelajaran sudah biasa. Dan pendapat mereka tentang guru yang menggunakan computer ketika proses pembelajaran mereka mengatakan lebih senang dan termotivasi dalam belajar.

Kemampuan keterampilan guru dalam menggunakan computer ketika proses pembelajaran masih tergolong sedang, sekitar $40 \%$ guru yang menggunakan media computer selebihnya masih menggunakan media pembelajaran yang konvensional dan sederhana

Sarana dan prasarana di SD 050664 Lubuk dalam tergolong baik, Aliran listrik seluruhnya beroprasi, Infokus ada 5 buah yang berfungsi 4 masih dalam proses perbaikan, Laptop juga ada 4 Unit yang tersedia di sekolah namun pada umumnya guru membawa laptop pribadi untuk mengajar.

Sekolah ini berada di pinggir jalan protocol sekitar 50 meter masuk kedalam dan sekolah dipagar keliling sehinggan anak-anak cukup aman di dalam, ada beberapa jalan kecil sebagai penghubung antara permukiman warga dan sekolah, tersedia musholla yyang sedang dalam proses pembangunan, Lokasi sekolah berada di sebelah permukiman warga, tanah lapang dan depan belakang di apit oleh beberapa sekolah.Setelah melakukan Observasi ke sekolah peneliti mengunjungi perpustakaan daerah Kabupaten Langkat yang berada di Kota Stabat guna mengumpulkan informasi terkait kearifan local budaya melayu, dan selanjutnya melakukan wawancara kepada bapak M. Sis seorang tokoh masyarakat melayu yang bertugas di Dinas pariwisata Kabupaten Langkat, Peneliti melakukan wawancara di kecamatan Tanjung Pura tepatnya di Museum Tanjung Pura. Peneliti mengumpulkan informasi berupa Sejarah, Pakaian Adat, Tarian Daerah, Lagu Daerah, Makanan Khas, dan Kebudayaan setempat dengan menggunakan catatan kecil serta merekam hasil dari wawancara Pada tahap ini dilakukan penyusunan draft awal (draft I) untuk merancang contoh (prototype) media pembelajaran dengan menggunkanan Adobe Flash.

Di desain dengan mengacu pada model Tutorial dimana program ini di realisasikan dalam bentuk prototype. Model tutorial merupakan bimbingan pembelajaran dalam bentuk pemberian arahan, bantuan, gambaran, dan petunjuk agar para siswa belajar secara efesien dan efektif sehingga memiliki sikap bertanggung jawab kepada diri sendiri yang tujuannya adalah meningkatkan hasil 
belajar serta pemahaman belajar. Selanjutnya instrumen penelitian yang lain seperti Angket siswa, dan lembar respon kepraktisan guru serta angket validator digunakan untuk melihat kelayakan media pembelajaran yang telah dikembangkan. Adapun langkah-langkahnya sebagai berikut :

a)Penyusunan Test

Soal disusun berdasarkan isi dan konteks dari media pembelajaran yang akan dikembangkan. Soal-soal evaluasi yang telah disusun kemudian dicari validitasnya. Soal yang valid akan dijadikan sebagai soal evaluasi pada media. Soal terdiri dari 15 soal pilihan ganda. Adapun hasil dari soal yang valid dan reliabel dapat dilihat pada Lampiran. Dari 15 soal yang uji validitas, daya beda dan tingkat kesukarannya sebanyak 4 soal dinyatakan tidak valid, maka hanya berjumlah 11 soal yang valid, namun soal yang digunakan hanya 10 soal diakrenakan dari 10 soal tersebut sudah mewakili seluruh sub bahasan yang telah dibuat. Berikut merupakan soal yang di gunakan.

Soal tes ini yang akan digunakan pada saat Pretes dan Postes untuk menentukan apakah media pembelajaran yang di kembangkan mampu meningkatkan pemahaman siswa terkait kearifan local budaya melayu.

Instrumen yang di gunakan untuk validasi ahli media dan desain pembelajaran, ahli bahasa, dan ahli materi, dan guru kelas dikembangkan sesuai kisi-kisi yang sudah di tetapkan.

Pemilihan format pengembangan media pembelajaran ini bertujuan untuk mendesain atau merancang isi pembelajaran,model media yang dikembangkan. Format yang dipilih adalah yang menarik perhatian siswa, mudah digunakan baik itu bagi guru maupun bagi siswa sendiri dan sesuai dengan lingkungan yang ada disekitar kehidupan sehari-hari siswa. Adapun format dalam penelitian ini diadopsi dengan model tutorial yang di buat oleh rusman kemudian di sesuaikan dengan kebutuhan siswa.

Media ini terdiri dari bagian intro (bagian pembuka). Halaman menu awal, berisi pilihan yang ada pada media tersebut terdapat opsi (Refrensi, Profil, Petunjuk penggunaan, Backsound, Tujuan umum dan khusus, Pembahasan). Halaman referensi, berisi daftar rujukan dalam pembuatan multimedia. Pengontrol musik latar, berisi fitur untuk mengontrol musik latar yang bisa diperdengarkan selama menggunakan multimedia. Keluar, berisi fitur untuk keluar dari program.

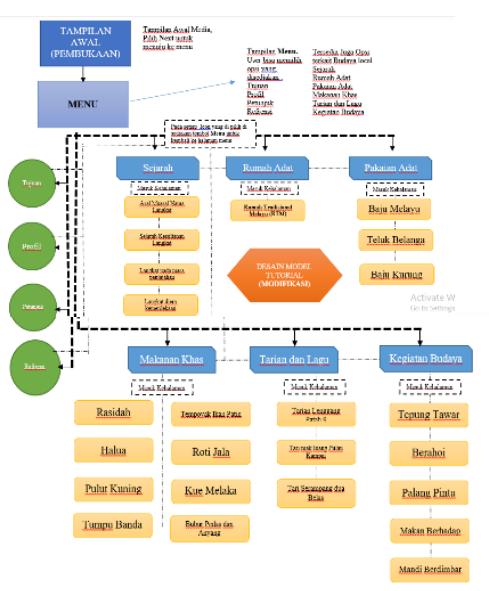

Gambar 2. Flowchart Media Pembelajaran

Adapun dalam penelitian ini peneliti menetapkan dan memilih software yang digunakan untuk membuat media pembelajaran antara lain adobe flash CS6 dan beberapa software pendukung lainnya seperti Swish

Windows Movie Maker dan Adobe Premiere Pro CS6. Adobe flash CS6 dipilih karena panel tools yang ada dalam software sangat mendukung untuk pembuatan animasi, pembuatan tombol dan dapat mengintegrasikan teks, gambar, animasi, suara, video menjadi sebuah media pembelajaran dengan menggunakan Action Script2.0.

Proses implementasi adalah kegiatan untuk merealisasikan rancangan desain dalam bentuk flowchart yang sebelumnya sudah dibuat menjadi desain yang lebih nyata dan layak digunakan 
1011 Pengembangan media pembelajaran budaya melayu dengan adobe flash berbasis kearifan lokal di sekolah dasar - Gihari Eko Prasetyo, Nurlia Ginting

sebagai media pembelajaran. Penulis mengumpulkan bahan-bahan yang diperlukan untuk membuat multimedia pembelajaran seperti animasi, musik, video, dan gambar kemudian mulai menerapkan rancangan awal (flowchart) yang telah dibuat sebelumnya ke media komputer menggunakan adobe flash CS6 Professional.

Animasi yang peneliti gunakan dalam penerapan media pembelajaran merupakan buatan dari peneliti sendiri dengan menggunakan adobe flash CS6 dengan beberapa software pendukung seperti windows movie maker, photo scape dan beberapa aplikasi lain, peneliti dapatkan dari google kecuali video pendukung materi yang berasal dari youtube. Hal ini terjadi karena keterbatasan peneliti dalam membuat animasi. Untuk musik latar yang peneliti gunakan adalah music instrumental.

Rancangan awal merupakan Tahapan yang dilakukan untuk membuat media pembelajaran yang disesuaikan dengan hasil wawancara dan tinjauan pustaka beberapa buku, tahap ini di isi dengan kegiatan menyiapkan kerangka media pembelajaran (materi, media, alat evaluasi) dan mensimulasikan media pembelajaran tersebut dalam lingkup kecil yaitu pada saat pembelajaran.

Berdasarkan kegiatan di atas dihasilkan sebuah media pembelajaran yang terdiri dari beberapa bagian, untuk lebih lengkapnya terdapat pada halaman lampiran.

Halaman pembuka terdiri dari musik latar dan animasi disertai dengan tombol Home untuk masuk ke menu.

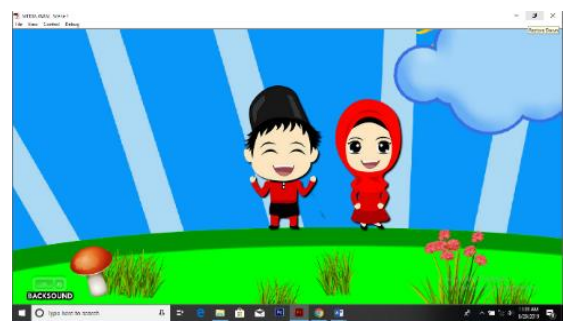

Gambar 3. Gambar Awal Media

Hasil halaman menu terdiri dari musik latar, layout dan animasi teks judul media, animasi nama pembuat media dan beberapa tombol menu, antara lain;, Tujuan, Profil, daftar pustaka dan pembehasan. Control untuk mengatur on/off music juga tersedia dihalaman menu utama.

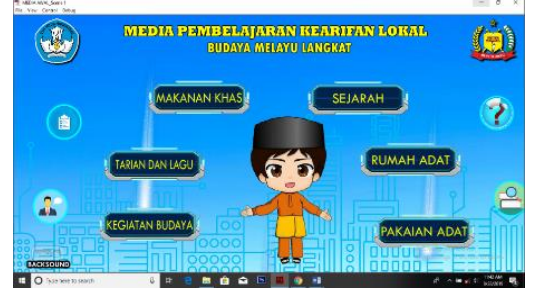

Gambar 4. Menu Utama Pembelajaran

Pada slide pembahasan terdapat beberapa bagian seperti , makanan khas, sejarah, tarian dan lagu, kegiatan budaya, rumah adat dan pakaian adat. Setiap icon membahas tentang judul yang berada pada tombol, misalnya pada bagian makanan khas maka isi dari tombol tersebut ialah macam-macam makanan khas dari kabupaten langkat.

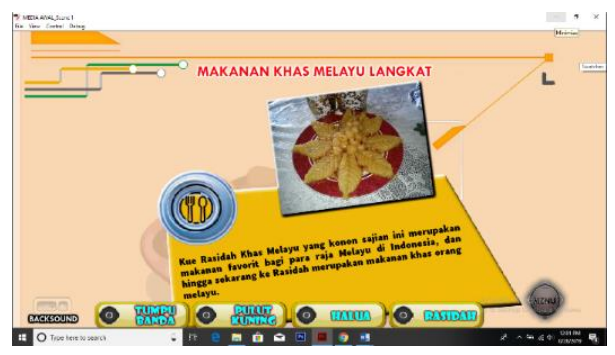

Gambar 4. Pembahasan makanan khas

Sebelum rancangan (design) produk dilanjutkan ke tahap berikutnya, maka rancangan produk tersebut perlu divalidasi. Validasi rancangan produk dilakukan oleh teman sejawat seperti dosen atau guru dari bidang studi/bidang keahlian yang sama. Berdasarkan hasil validasi teman sejawat tersebut, ada kemungkinan rancangan produk masih perlu diperbaiki sesuai dengan saran validator, namun perangkat yang divalidasi telah siap digunakan namun masih perlu revisi kecil untuk proses kecil jika terdapat kekurangan kedepannya.

Hasil dari tahap define dan design menghasilkan rancangan awal sebuah perangkat 
1012 Pengembangan media pembelajaran budaya melayu dengan adobe flash berbasis kearifan lokal di sekolah dasar - Gihari Eko Prasetyo, Nurlia Ginting

pembelajaran yang disebut dengan draft $\mathrm{I}$. selanjutnya yaitu tahap develop atau tahap pengembangan. Fase pertama pada tahap pengembangan adalah melakukan validasi draft $I$. Validasi para ahli difokuskan kepada ahli media dan desain, ahli bahasa dan ahli materi. Hasil validasi berupa nilai validasi, koreksi, kritik dan saran yang yang digunakan sebagai daasar untuk melakukan revisi dan penyempurnaan perangkat pembelajaran yang telah memenuhi kriteria Valid dan selanjutnya disebut dengan Draft II. Berikut merupakan hasil validasi para ahli yang :

Tabel 4. Rekapitulasi Hasil Validasi

\begin{tabular}{|c|c|c|}
\hline \multirow{2}{*}{ Validasi Ahli } & \multicolumn{2}{|c|}{ Persentase Skor } \\
\cline { 2 - 3 } & $\begin{array}{c}\text { Tahap } \\
\text { I }\end{array}$ & $\begin{array}{c}\text { Tahap } \\
\text { II }\end{array}$ \\
\hline Ahli Media dan Desain & $53 \%$ & $86 \%$ \\
\hline Ahli Bahasa & $56 \%$ & $89 \%$ \\
\hline Ahli Materi & $57 \%$ & $84 \%$ \\
\hline Kepraktisan (Guru) & $60 \%$ & $92 \%$ \\
\hline
\end{tabular}

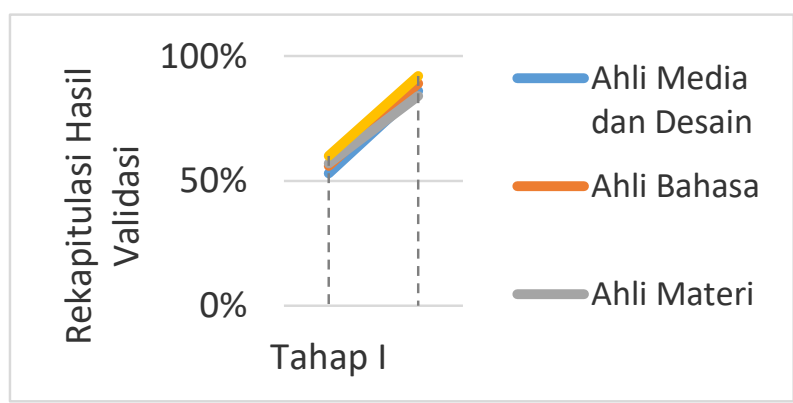

Gambar 5. Diagram Hasil Validasi

Pada diagram diatas dapat dipahami bahwa media yang dikembangkan dalam tahap Develeop dinyatakan sudah Valid dan Praktis. Hal tersebut dapat dilihat dari peningkatan dari Tahap I ke tahap II dan seluruh aspek validitas dalam kriteria sangat valid dan Sangat Praktis.

Setelah media dinyatakan Valid dan Praktis maka media pembelajaran sudah bias di ujicobakan. Pada uji coba I siswa diberikan 10 buah soal pilihan berganda sebagai instrumen tes pada postes. Nilai hasil postes dapat dilihat pada lampiran hasil postes siswa. Secara umum, analisis data efektifitas media pembelajaran yang digunakan siswa

Dari 20 orang siswa yang mengikuti pretest hanya 4 orang atau $20 \%$ yang dinyatakan tuntas dengan mendapat skor 7, dan 16 lainnya atau 80\% dinyatakan tidak tuntas. Kemudian setelah dilakukannya treatment dan dilakukan posttest jumlah siswa yang tuntas meningkat menjadi 14 orang atau $70 \%$ dan hanya 6 orang atau $30 \%$ yang dinyatakan tidak tuntas.

Hasil perhitungan dengan menggunakan Ms Excel diperoleh rata-rata nilai Gain sebesar 0,4. Nilai gain ini selanjutnya di interpretasikan kedalam kriteria nilai gain dimana dalam kategori Sedang. Dengan hasil tersebut dapat disimpulkan bahwa siswa yang menggunakan media pembelajaran dengan menggunakan adobe flash dapat meningkatkan Pemahaman siswa tentang Kearifan Lokal budaya melayu.

\section{SIMPULAN}

Pengembangan media pembelajaran dengan menggunakan model 4-D dari Thiagarajan telah menghasilkan media pembelajaran yang valid dan efektif serta praktis. Dari hasil penelitian yang telah dilakukan dapat diuraikan kesimpulan sebagai berikut: Media pembelajaran telah memenuhi kriteria valid dilihat dari hasil validsai ahli media dan desain, ahli bahasa dan ahli materi yang ketiganya dalam kategori sangat valid. Media pembelajaran telah memenuhi kriteria praktis dilihat dari angket kepraktisan guru/user yang dalam kategori sangat praktis. Media pembelajaran telah memenuhi kriteria efektif dilihat dari Gain Score sebesar 0,4 yang dalam kategori Sedang.

Perlu adanya analisis dan pengembangan yang lebih meluas sehingga media tidak hanya bisa di terapkan di sekolah dasar, namun bisa untuk kalangan umum sebagai penambah wawasan 
1013 Pengembangan media pembelajaran budaya melayu dengan adobe flash berbasis kearifan lokal di sekolah dasar - Gihari Eko Prasetyo, Nurlia Ginting

kearifan local budaya melayu.

Perlu kiranya media pembelajaran ini dilengkapi dengan buku penjelasan (manual book) agar lebih mudah memahami konteks dari media

CD Pembelajaran ini

\section{UCAPAN TERIMAKASIH}

Peneliti mengucapkan terimakasih kepada Kemenristekdikti yang menjadi pendukung atas terlaksananya penelitian ini dalam program penelitian hibah dosen pemula, serta kepada LPPM Universitas Quality Berastagi yang membantu proses berjalanan penelitian ini.

\section{DAFTAR PUSTAKA}

Kristiyanto E. N. 2017. Kedudukan Kearifan Lokal dan Peranan Masyarakat dalam Penataan Ruang di Daerah, Jurnal Rechtsvinding Media Pembinaan Hukum Nasional , 6 (2), $159-177$

Atapukang N. 2016 Kreatif Membelajarkan Dengan Menggunakan Media pembelajaran yang Tepat Sebagai Solusi Dalam Berkomunikasi, Jurnal Media Komunikasi Geografi, 17 (2) 45-52

Sari Lapita H. 2011. Media Pembelajaran Kimia Terpadu pada Madrasah Tsanawiyah Negeri MAN 2 Kota Bengkulu, Jurnal Media Infotama, 7 (2), 103-120

Firmantoro K, Anton, Nainggolan Esron R. 2016. Animasi Interaktif Pengenalan Hewan untuk Pendidikan Anak Usia Dini. Jurnal Techno Nusa Mandiri, 13 (2), 15-22

Nieveen Nienke \& Plomp T.2013. Educational Design Research, Netherlands institute for curriculum development, 29 